\title{
Temperature-dependent impacts of allelopathy on growth, pigment, and lipid content between a subpolar strain of Synechocystis sp. CCBA MA-01 and coexisting microalgae
}

\author{
Aldo Barreiro Felpeto · Sylwia Śliwińska-Wilczewska $(\mathbb{D} \cdot$ Marek Klin • \\ Zofia Konarzewska $\cdot$ Vitor Vasconcelos
}

Received: 26 July 2018/Revised: 5 March 2019/Accepted: 6 March 2019/Published online: 13 March 2019

(C) The Author(s) 2019

\begin{abstract}
Picocyanobacteria represent the main fraction of ocean primary production and, due to the effects of ocean acidification and an increase in seawater temperature, this group is expected to be favored in future scenarios. For this reason, we studied the ecophysiological response of picocyanobacteria to increases in water temperature by testing the allelopathic activity of a subpolar strain of Synechocystis sp., grown at a temperature range of $10-20^{\circ} \mathrm{C}$, against coexisting microalgae. We showed that cell-free filtrates of Synechocystis sp. inhibited growth and the maximum quantum yields of PSII $\left(F_{\mathrm{v}} / F_{\mathrm{m}}\right)$ of Porphyridium purpureum, Fistulifera sp., and Chlorella vulgaris, and the negative effect of the
\end{abstract}

Handling editor: Jonne Kotta

A. B. Felpeto · V. Vasconcelos

Interdisciplinary Center of Marine and Environmental Research-CIMAR/CIIMAR, University of Porto, Av. General Norton de Matos s/n, 4450-208 Matosinhos, Portugal

S. Śliwińska-Wilczewska $(\bowtie) \cdot$ M. Klin .

Z. Konarzewska

Institute of Oceanography, University of Gdansk, Av. Pilsudskiego 46, 81-378 Gdynia, Poland

e-mail: ocessl@ug.edu.pl

V. Vasconcelos

Department of Biology, Faculty of Sciences, Porto University, Rua do Campo Alegre, 4069-007 Porto, Portugal picocyanobacterium was stronger at the highest temperatures at which Synechocystis sp. was grown. Similarly, in $P$. purpureum, the effect of filtrates reduced chlorophyll $a$ (Chl $a$ ) and carotenoids (Car) content, and the effect depended on the temperature at which the picocyanobacterium was grown. The lipid content was observed to increase in all species, and the allelopathic effect was the strongest at the highest temperature in which Synechocystis sp. was grown. The results of the present study predict a stronger allelopathic effect of picocyanobacteria against competitors with rising temperatures. They also suggest that the potential effect of climate change would benefit this group in future phytoplankton communities.

Keywords Allelopathy $\cdot$ Climate change $\cdot$ Harmful algal bloom $\cdot$ Microalgae $\cdot$ Picocyanobacteria

\section{Introduction}

Picocyanobacteria are cosmopolitan organisms which dominate primary production in the open ocean (Callieri, 2010; Worden \& Wilken, 2016). Picocyanobacteria also are able to produce a variety of bioactive and allelopathic compounds, which could have a negative impact in many organisms of the ecosystem, from microbes to plants and animals (Śliwińska-Wilczewska et al., 2018a). They also form 
harmful blooms in marine ecosystems, which may span over large areas (Beardall, 2008; Sorokin \& Dallocchio, 2008; Sorokin \& Zakuskina, 2010). These blooms could negatively impact seagrass beds and corals communities (Hall et al., 1999). Sorokin \& Zakuskina (2010) also reported that blooms of picocyanobacteria can cause mortality of bottom vegetation and benthic fauna. Furthermore, picocyanobacterial blooms are also known to inhibit zooplankton grazing (Goleski et al., 2010). Specific studies are needed to describe the drivers of these blooms. Currently, these are considered complex events, caused by multiple factors occurring simultaneously (Heisler et al., 2008).

According to the literature, allelopathy is a potential driver of the development of blooms and plankton community dynamics (Kubanek et al., 2005; Prince et al., 2008; Hattenrath-Lehmann \& Gobler, 2011; Franzè et al., 2018). The number of reports on the allelopathic activity of cyanobacteria has been steadily increasing (e.g., Brutemark et al., 2015; Costa et al., 2015; Dias et al., 2017). There are some reports of allelopathic effects such as growth inhibition or stimulation caused by picocyanobacterium Synechococcus sp. C.Nägeli (e.g., Barreiro Felpeto et al., 2018; Śliwińska-Wilczewska \& Latała, 2018), but no information about the allelopathic activity of Synechocystis sp. on coexisting microalgae has been found.

Synechocystis sp. Wislouch, alongside Synechococcus sp. and Prochlorococcus sp. Chisholm, Frankel, Goericke, Olson, Palenik, Waterbury, West-Johnsrud $\&$ Zettler, is an important primary producer, especially in oceanic waters during summer (Lochte \& Turley, 1988). Synechocystis sp. occurs numerously, e.g., in the Baltic Sea and the Atlantic Ocean (Möller \& Jansson, 1997; Martins et al., 2005, 2007, 2008). Moreover, Vareli et al. (2012) noted that the cyanobacterial community was found to be dominated almost exclusively by the cosmopolitan species Synechococcus and Synechocystis in the Mediterranean Sea. According to the best knowledge of the authors, there are no literature reports about the blooms of Synechocystis sp. It was argued that allelopathy could only be effective at cell abundances close to blooming conditions (Jonsson et al., 2009) mainly due to the large cell-to-cell distances that occur in the real ecosystems. However, there are still many unknown facts regarding the mechanism of action of allelochemicals, which might not need to reach high concentrations in order to be effective (Lewis, 1986). Recent papers showed significant effects of diatom allelochemicals, at low concentrations, in field planktonic food webs (Franzè et al., 2018).

Among secondary metabolites, there are many different active compounds that have an allelopathic effect. Inhibition of growth is the most frequently described mode of action. Some studies indicate that allelopathic compounds can also affect lipid content of target organisms. Poulson-Ellestad et al. (2014) demonstrated that the fatty acid syntheses of two competing phytoplanktons, Asterionellopsis glacialis (Castracane) Round and Thalassiosira pseudonana Hasle \& Heimdal, were disrupted due to Karenia brevis (C.C.Davis) Gert Hansen \& Moestrup allelopathy. Also, Poulin et al. (2018) showed that allelochemicals induced changes in lipid composition, in part due to the use of various lipids as signal molecules during stress. An indirect effect of picocyanobacterial allelochemicals in photosynthesis is by altering the pigment content. Śliwińska-Wilczewska et al. (2017) showed that filtrates from picocyanobacterium Synechococcus sp. caused significant reductions in the chlorophyll content of Phormidium sp. Kützing ex Gomont and Rivularia sp. C.Agardh ex Bornet \& Flahault cells and increased the carotenoid contents of Anabaena flos-aquae Ralfs ex Bornet \& Flahault and Nostoc sp. Vaucher ex Bornet \& Flahault. Similarly, Barreiro Felpeto et al. (2018) demonstrated that Synechococcus sp. allelochemicals caused reductions of chlorophyll content of Nodularia spumigena Mertens ex Bornet \& Flahault. Considering all this knowledge, we decided to consider the following ones as response variables: growth in terms of cell numbers, ratio $F_{\mathrm{v}} / F_{\mathrm{m}}$, and pigment and lipid compositions.

It has also been shown that an increase in surface water temperature, an indicator of global change, could have a positive effect in the development of cyanobacterial blooms (Paul, 2008; Paerl \& Huisman, 2009). In the current century, average global temperatures are expected to increase in the range of $1.5-5^{\circ} \mathrm{C}$ (Houghton et al., 2001; IPCC, 2007). As surface water temperatures approach and exceed $20^{\circ} \mathrm{C}$, the growth rates of eukaryotic phytoplankton generally stabilize or decrease, while growth rates of many cyanobacteria keep increasing (Paerl \& Huisman, 2009). Focusing on picocyanobacteria, these usually achieve maximal growth rates at higher temperatures than other cyanobacteria (Moore et al., 1995) and thus will 
potentially be favored by global warming. Moreover, it was reported that the ability of picocyanobacterium Synechococcus sp. to produce allelopathic compounds is being affected by temperature (Śliwińska-Wilczewska et al., 2016). Thus, considering all the knowledge available, it is expected that massive blooms of picocyanobacteria will be more frequent under future scenarios predicted by global change, and allelopathy of these species should also be a factor to be taken into account. However, the allelopathic activity of the picocyanobacterium Synechocystis sp. targeted at coexisting microalgae has never been investigated, although some previous works have suggested that these species produce biologically active compounds, i.e., microcystins (Oudra et al., 2002), $\beta$-Methylamino-L-alanine (Cianca et al., 2012), and lipopolysaccharides (Schmidt et al., 1980).

The main aim of this work was to study the allelopathic activity, and its temperature dependence, of the picocyanobacterium Synechocystis (MA-01) against the coexisting eukaryote microalgae Porphyridium purpureum (Bory) K.M.Drew \& R.Ross, Fistulifera sp. S.Mayama, M.Matsumoto, K.Nemoto \& T.Tanaka, and Chlorella vulgaris Beyerinck [Beijerinck]. We tested the influence of cell-free filtrate obtained from Synechocystis cultures grown under different temperatures on the following parameters: growth, the maximum quantum yield of PSII, as well as pigment and lipid contents. This study will be useful to better understand the extent to which rising temperatures, as a global change indicator, could influence picocyanobacterial dominance in high northern latitudes.

\section{Materials and methods}

Material and culture conditions

The strains employed in the experiments were, as a donor of allelochemicals, the picocyanobacterium Synechocystis sp. (MA-01), and as targets: the red algae Porphyridium purpureum (MA-04), the diatom Fistulifera sp. (MA-14) and the green algae Chlorella vulgaris (MA-24). All these strains were isolated from the coastal zone of Norway, in the Norwegian Sea or the Greenland Sea. They were maintained as unispecies cultures in the Culture Collection of Baltic
Algae (CCBA) at the Institute of Oceanography, University of Gdańsk, Poland.

Cultures were grown in $\mathrm{f} / 2$ medium (Guillard, 1975) in 25-ml glass Erlenmeyer flasks that were swirled daily during the experimental period. Culture media was prepared with artificial seawater filtered through glass fiber filters (Whatman GF/C) and autoclaved. The salinity was 32 PSU, measured with salinometer (inoLab Cond Level 1, Weilheim in Oberbayern, Germany). The conditions in the culture room were 16:8 h light:dark cycle with Photosynthetically Active Radiation (PAR) irradiance of $20 \mu \mathrm{mol}$ photons $\mathrm{m}^{-2} \mathrm{~s}^{-1}$ and $10^{\circ} \mathrm{C}$. Target microalgae were grown during 7 days under constant conditions of $10^{\circ} \mathrm{C}$ and $32 \mathrm{PSU}$, under a $16: 8 \mathrm{~h}$ light:dark cycle at $20 \mu \mathrm{mol}$ photons $\mathrm{m}^{-2} \mathrm{~s}^{-1}$. These growth conditions were used for control. The donor species, the picocyanobacteria Synechocystis sp. was grown at three different temperatures: 10,15 , and $20^{\circ} \mathrm{C}$. All picocyanobacterial cultures were maintained for 7 days in order to allow them to acclimate and reach the exponential growth phase when they will be employed in the experiments.

Test of the allelopathic effect of cell-free filtrates

After the 7 days of acclimation, the concentrations of macronutrients (i.e., nitrate, $\mathrm{N}-\mathrm{NO}_{3}$, and $\mathrm{P}-\mathrm{PO}_{4}$ orthophosphates) were measured in the donor picocyanobacterial cultures, and then they were readjusted to the standard levels of the $f / 2$ medium. Nutrients were determined using spectrophotometric methods as described by Grasshoff (1976). Then, cultures from each temperature condition were filtered through a $0.45-\mu \mathrm{m}$ filter (Macherey-Nagel MN GF-5) using a vacuum pump (400 mbar). The filtrates were then analyzed on an epifluorescence microscope (Nikon Eclipse 80i, Nikon, Tokyo, Japan) to confirm the absence of picocyanobacteria. These cell-free filtrates were then employed to test allelopathic activity, following a similar protocol to that of Suikkanen et al. (2004). We tested the allelopathic activity of Synechocystis sp. on coexisting microalgae by a single addition of cell-free filtrate. $10 \mathrm{ml}$ of the cell-free filtrate obtained from each of the temperature regimes were separately added to 25-ml Erlenmeyer flasks containing $10 \mathrm{ml}$ of cell suspensions of the target microalgae species, obtained from the exponentially growing cultures referred in the section above. 
Controls consisted of adding $10 \mathrm{ml}$ of filtered $\mathrm{f} / 2$ medium to 25-ml Erlenmeyer flasks containing $10 \mathrm{ml}$ of cell suspensions of the same microalgae species and kept in the same culturing conditions as described above for the target species. Three replicates were employed in all treatments and control. The ratio of donor picocyanobacteria to target species was adjusted to $1: 1$ based on the chlorophyll $a(\mathrm{Chl} a)$ content (the initial Chl $a$ concentration in the experimental cultures was $0.4 \mu \mathrm{g} \mathrm{Chl} a \mathrm{ml}^{-1}$ ). The experiments lasted for 7 days. On the first and the last days of the experiment, the $\mathrm{pH}$ values of the treatments and controls were measured using $\mathrm{pH}$-meter (Elmetron CP-401, Zabrze, Poland). pH values were similar between treatments and the initial and final time points, which ranged from 7.9 to 8.3 .

Determination of cell abundances

Cell abundances were estimated with previously determined linear regression models between the number of cells $\left(\mathrm{N} \mathrm{ml}^{-1}\right.$ ) and optical density (OD). Cyanobacterial and microalgal cells were counted using flow cytometer BD Accuri ${ }^{\mathrm{TM}}$ C6 Plus (BD Biosciences, San Jose, CA, USA) calibrated with SPHERO $^{\mathrm{TM}}$ Rainbow Calibration Particles (BD, San Jose, USA). OD was measured spectrophotometrically at $750 \mathrm{~nm}$ with a Multiskan GO UV-Vis spectrophotometer (Thermo Scientific, Massachusetts, USA). These data were used to fit a linear regression model between the variables $\mathrm{N}$ and $\mathrm{OD}$. The linear correlation between N and OD for Synechocystis sp. was $y=78.3 \times 10^{6} x+21.2 \times 10^{4} ; \quad(r=0.97), \quad$ where $y=\mathrm{N}\left(\mathrm{ml}^{-1}\right)$ and $x=\mathrm{OD}$. For P. purpureum, Fistulifera sp., and $C$. vulgaris, the correlation coefficients for their respective linear regression models were $r=0.99, r=0.99$, and $r=0.98$, respectively, and the model equations: $y=52.9 \times 10^{5-}$ $x+8.4 \times 10^{3}, y=23.0 \times 10^{6} x-7.7 \times 10^{4}$ and $y=18.3 \times 10^{6} x+6.5 \times 10^{4}$, respectively, where $y=\mathrm{N}\left(\mathrm{m} \mathrm{l}^{-1}\right)$ and $x=\mathrm{OD}$. Cell abundances were estimated in all the experiments performed at following days: zeroth day $(1 \mathrm{~h})$ and $1 \mathrm{st}, 3 \mathrm{rd}$, and 7 th days of the experiment and control.
Measurements of the maximum quantum yield of PSII

The maximum PSII quantum efficiency was calculated as $F_{\mathrm{v}} / F_{\mathrm{m}}$ (where $F_{\mathrm{v}}$-the difference between the maximum and minimum fluorescence; and $F_{\mathrm{m}}-$ the maximum fluorescence) (Campbell et al., 1998). Chlorophyll $a$ fluorescence was measured using a Pulse Amplitude Modulation (PAM) fluorometer (FMS1, Hansatech), equipped with a 594-nm amber modulating beam with a 4-step frequency control serving as a measuring light. Samples were taken at the following days: $0(1 \mathrm{~h})$, the $1 \mathrm{st}$, the $3 \mathrm{rd}$, and the $7 \mathrm{th}$ days of the experiment. Samples were filtered through 13-mm glass fiber filters (Whatman GF/C). Before measurements, the filtered sample was kept in the dark for approximately $10 \mathrm{~min}$ (Śliwińska-Wilczewska et al., 2016).

Measurements of pigment content

The concentration of photosynthetic pigments of target microalgae was measured by spectrophotometry on the 7th day of the experiment. Chl $a$ and Car concentrations were extracted with cold $90 \%$ acetone in the dark for $2 \mathrm{~h}$ at $-60^{\circ} \mathrm{C}$. To remove cell debris and filter out particles, these extracts were centrifuged at $13,000 \mathrm{rpm}(14,359 \times \mathrm{g})$ for $2 \mathrm{~min}$ (Sigma 2-16P, Osterode am Harz, Germany). The extinction values were determined as 480, 664, and $750 \mathrm{~nm}$ using a DU530 UV-VIS Life Science spectrophotometer (Beckman, California, USA). The concentrations of Chl $a$ and Car were calculated according to Strickland \& Parsons (1972).

\section{Measurements of lipid content}

The total lipid content of target microalgae was measured on the 7th day of the experiment. Quantitative measurements of lipids were performed using the optimized colorimetric sulphophospho-vanilin method proposed by Klin et al. (2018). Bligh and Dyer (1959) demonstrated that the results of separation of lipids and nonlipids in this method were reproducible to within $\pm 2 \%$; therefore, loss of lipids through incomplete partitioning in our experiment can be excluded. The concentration of lipids was estimated based on the calibration curve that was developed using high-quality soybean oil as a source of fatty 
acids, which has a similar composition of lipids compared to algae (Grama et al., 2014). For the extraction, $1 \mathrm{ml}$ aliquots of microalgal cultures were centrifuged at 10,000 rpm $(8496 \times g)$ for $5 \mathrm{~min}$ (Sigma 2-16P, Osterode am Harz, Germany) and resuspended in $0.5 \mathrm{ml}$ of methanol. Subsequently, $1 \mathrm{ml}$ of chloroform was added. The resuspended samples were centrifuged $(8496 \times g, 5 \mathrm{~min})$, and the supernatant was collected and supplemented with $0.2 \mathrm{ml}$ of $0.8 \%$ $\mathrm{NaCl}$ solution. At that point, samples were allowed to remain at room temperature, until two layers were formed, and then the upper layer was collected and discarded. The lower layer was dried under $\mathrm{N}_{2}$ at $50^{\circ} \mathrm{C}$. Next, $0.3 \mathrm{ml}$ of concentrated sulfuric acid was added to the samples and then heated at $90^{\circ} \mathrm{C}$ for $10 \mathrm{~min} .1 \mathrm{ml}$ of SPV reagent $(1.2 \mathrm{~g}$ vanillin per $11 \mathrm{of}$ $68 \%$ phosphoric acid) was added in order to fully stain the fatty acids. Then, the samples were incubated at $36^{\circ} \mathrm{C}$ for $5 \mathrm{~min}$. The absorbance of the final solution was measured at $525 \mathrm{~nm}$.

\section{Statistical analyses}

A general linear model was used to test the effect of picocyanobacterial filtrates obtained from cultures grown under different temperatures on growth and the maximum quantum yield of PSII of the targeted microalgae. The treatment (temperature) was used as a categorical factor and time (day) as a covariate. A post hoc least significant distance (LSD) test was used to test significant differences between combinations of treatment levels (comparisons were reported only for the pairs control $v s$ treatment within the same day). Independent sample $t$ tests assuming equal variances were applied to determine the effect of cell-free filtrates on pigment and lipid contents of the target species. The statistical analyses were performed using $R$ (R Core Team 2017) and Statistica ${ }^{\circledR}$ software.

\section{Results}

Allelopathic effect of cell-free filtrates on growth

The addition of cell-free filtrate obtained from Synechocystis sp. significantly affected the number of cells of $P$. purpureum, Fistulifera sp. and $C$. vulgaris (Table 1). The target species had positive growth during the seven days of the experiments, in the majority of treatments (Fig. 1). The factors 'Treatment' and 'Days' showed a significant interaction in all three species (Table 1). This could be expected for two main reasons: (1) the effect of time must be significant in the model (the algae are growing), and then, the effects of the treatment would be apparent mostly in the last days of the experiments; and (2) if there is a temperature-dependent effect, there will always be an interaction between the two factors. Because of this interaction, the significance values of the other main effects ('Treatment,' 'days') are not directly interpretable. For these reasons, in order to compare the effect of different temperatures, we should look at the results of the pairwise comparisons between the control and the different levels of temperature, within each time step, performed with LSD (see asterisks in Fig. 1). In P. purpureum, cellfree filtrates from all three temperatures produced a significant effect. It was found that the addition of cellfree filtrates obtained from Synechocystis sp. significantly affected the number of cells of $P$. purpureum, and the negative effect was amplified with the increasing temperature at which picocyanobacterium was grown. In Fistulifera sp., this effect was only significant for the filtrate from $20^{\circ} \mathrm{C}$, but in $C$. vulgaris, it was significant for the filtrate from all three temperatures, without distinction between them. At the end of the experiment, the growths of $P$. purpureum relative to the control were 87,84 , and $73 \%$, observed for the cell-free filtrates from 10, 15, and $20^{\circ} \mathrm{C}$, respectively. All these constituted significant differences, according to the LSD test (Fig. 1). For Fistulifera sp., the corresponding amounts were 95,88 , and $44 \%$ for 10,15 , and $20^{\circ} \mathrm{C}$, respectively, constituting significant differences only for the two highest temperatures (Fig. 1). And, for C. vulgaris, they were 74,74 , and $69 \%$, for 10,15 , and $20^{\circ} \mathrm{C}$, respectively, constituting significant differences for all of them.

Allelopathic effect of cell-free filtrates on the maximum quantum yield of PSII

The cell-free filtrates obtained from Synechocystis sp. had a negative effect in the maximum PSII quantum efficiency of all the three species (Table 2, Fig. 2). For C. vulgaris, in the pairwise comparisons by LSD, there were no significant differences between any of the control-treatment pairs. In these data, because there 
Table 1 Results of the analysis of variance applied to the linear model fitted to the growth data in the three species

\begin{tabular}{lllll}
\hline Independent variable & $F$ & $d f$ (factor) & $d f$ (residual) & $P$ \\
\hline $\begin{array}{l}\text { Porphyridium purpureum } \\
\text { Temperature }\end{array}$ & 14.8 & 3 & 40 & $<0.001$ \\
Days & 493 & 1 & & $<0.001$ \\
Temperature $\times$ days & 9.7 & 3 & & $<0.001$ \\
Fistulifera sp. & & & 40 & $<0.001$ \\
Temperature & 44.7 & 3 & & $<0.001$ \\
Days & 447 & 1 & & $<0.001$ \\
Temperature $\times$ days & 45.1 & 3 & 40 & $<0.001$ \\
Chlorella vulgaris & & & & $<0.001$ \\
Temperature & 12.9 & 3 & & $<0.001$ \\
Days & 228 & 1 & & \\
Temperature $\times$ days & 9.6 & 3 & & \\
\hline
\end{tabular}
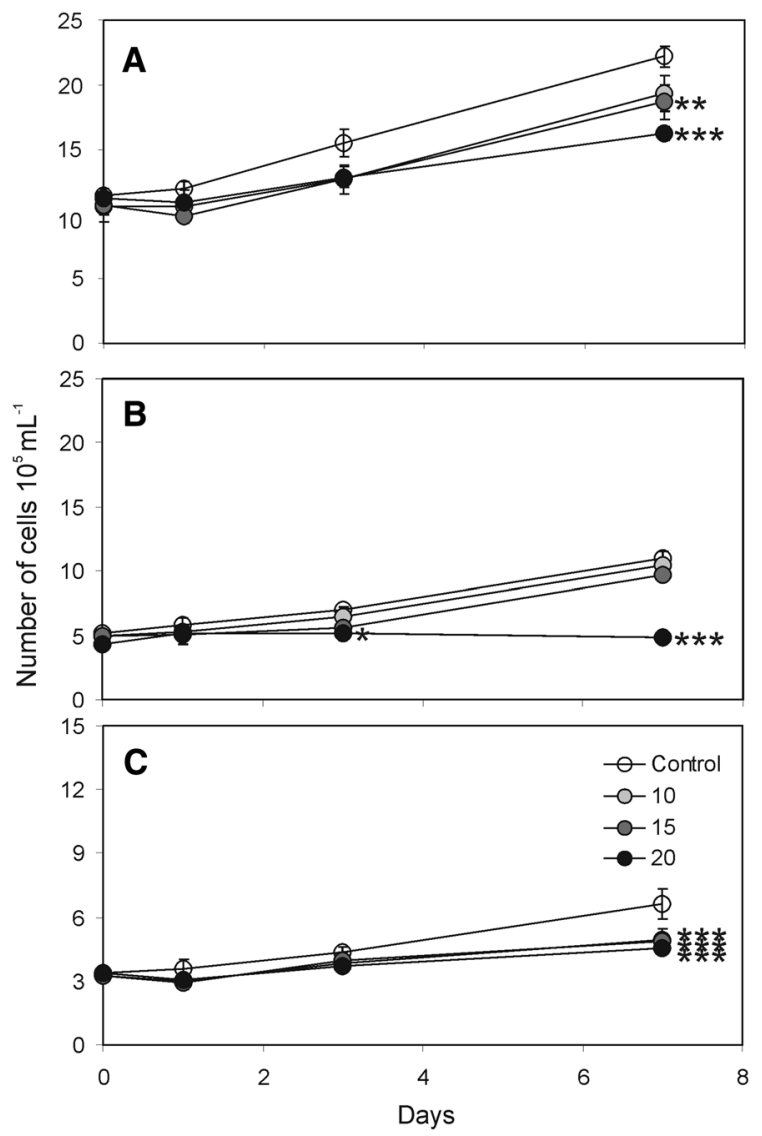

Fig. 1 The number of cells (N) of P. purpureum (A), Fistulifera sp. (B), and C. vulgaris $(\mathbf{C})$ employed as a target for the Synechocystis sp. cell-free filtrate obtained from cultures grown under different temperatures. Values are mean \pm SD $(n=3)$. Asterisks indicate level of significance from post hoc LSD tests of single temperature level compared to control $(* P<0.05 ; * * P<0.01 ; * * * P<0.001)$ was no interaction between 'Temperature' and 'Days,' it was possible to perform a post hoc Dunnett test to detect significant differences between the control and the different levels of temperature. In this test, significant differences were found between the control and both $15^{\circ} \mathrm{C}(t=-3.8, P<0.01)$ and $20^{\circ} \mathrm{C}$ $(t=-4.7, P<0.001)$. For P. purpureum and Fistularia sp., the existence of the interaction between the factors 'Temperature' and 'Days' prevents a straightforward interpretation of the significance of each main effect individually. By comparing the control against the different temperature levels by LSD, significant effects of the filtrates from $20^{\circ} \mathrm{C}$ treatment on days 1 , 3 , and 7 for $P$ purpureum, were found with the fluorescence parameter $F_{\mathrm{v}} / F_{\mathrm{m}}$ values on these days being 87,84 , and $69 \%$ of the control, respectively. In the same species, the filtrate from $15^{\circ} \mathrm{C}$ also showed a significant difference on the seventh day. In Fistularia sp., filtrates from $15^{\circ} \mathrm{C}$ and $20^{\circ} \mathrm{C}$ only showed significant differences on the seventh day, the $F_{\mathrm{v}} / F_{\mathrm{m}}$ parameter values in those cases being $93 \%$ and $84 \%$ of the control, respectively. All these results indicate a stronger allelopathic effect of the filtrates of cultures from higher temperatures.

Allelopathic effects of cell-free filtrates on pigment content

In $P$. purpureum, the addition of cell-free filtrate obtained from Synechocystis sp. reduced both the Chl $a$ and Car contents per cell (Fig. 3A). This reduction was temperature dependent-the stronger the reduction, the higher the temperature. In comparison with 
Table 2 Results of the analysis of variance applied to the linear model fitted to the maximum quantum yield of PSII data in the three species

\begin{tabular}{lllll}
\hline Independent variable & $F$ & $d f$ (factor) & $d f$ (residual) & $P$ \\
\hline $\begin{array}{l}\text { Porphyridium purpureum } \\
\text { Temperature }\end{array}$ & 38.6 & 3 & 40 & $<0.001$ \\
Days & 16.5 & 1 & & $<0.001$ \\
Temperature $\times$ days & 20.4 & 3 & & $<0.001$ \\
Fistulifera sp. & & & 40 & $<0.001$ \\
Temperature & 11.6 & 3 & & $<0.001$ \\
Days & 102 & 1 & & $<0.001$ \\
Temperature $\times$ days & 14.9 & 3 & 40 & $<0.001$ \\
Chlorella vulgaris & & & & $<0.01$ \\
Temperature & 8.9 & 3 & & 0.63 \\
Days & 9.1 & 1 & & \\
Temperature $\times$ days & 0.58 & 3 & & \\
\hline & & & & \\
\end{tabular}

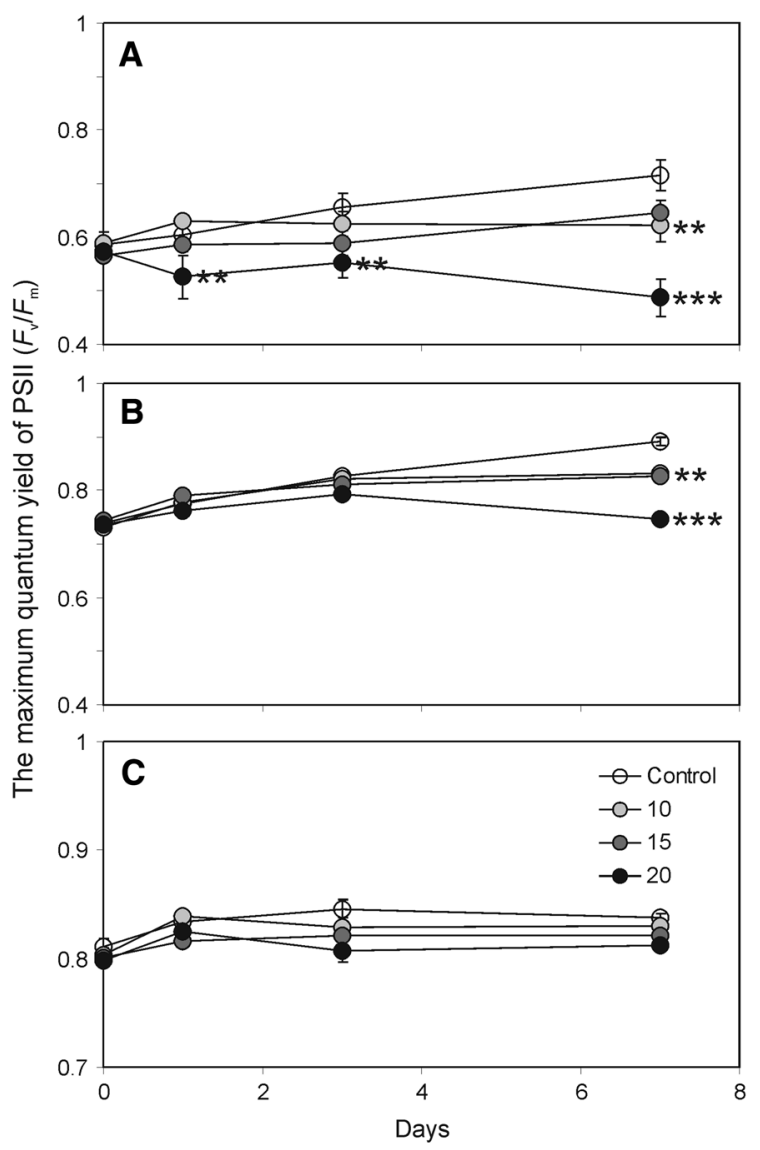

Fig. 2 The maximum quantum yields of PSII $\left(F_{\mathrm{v}} / F_{\mathrm{m}}\right)$ of $P$. purpureum (A), Fistulifera sp. (B), and C. vulgaris (C) employed as a target for the Synechocystis sp. cell-free filtrate obtained from cultures grown under different temperatures. Values are mean $\pm \mathrm{SD}(n=3)$. Asterisks indicate level of significance from post hoc LSD tests of single temperature level compared to control $(* P<0.05 ; * * P<0.01$; ***P $<0.001)$

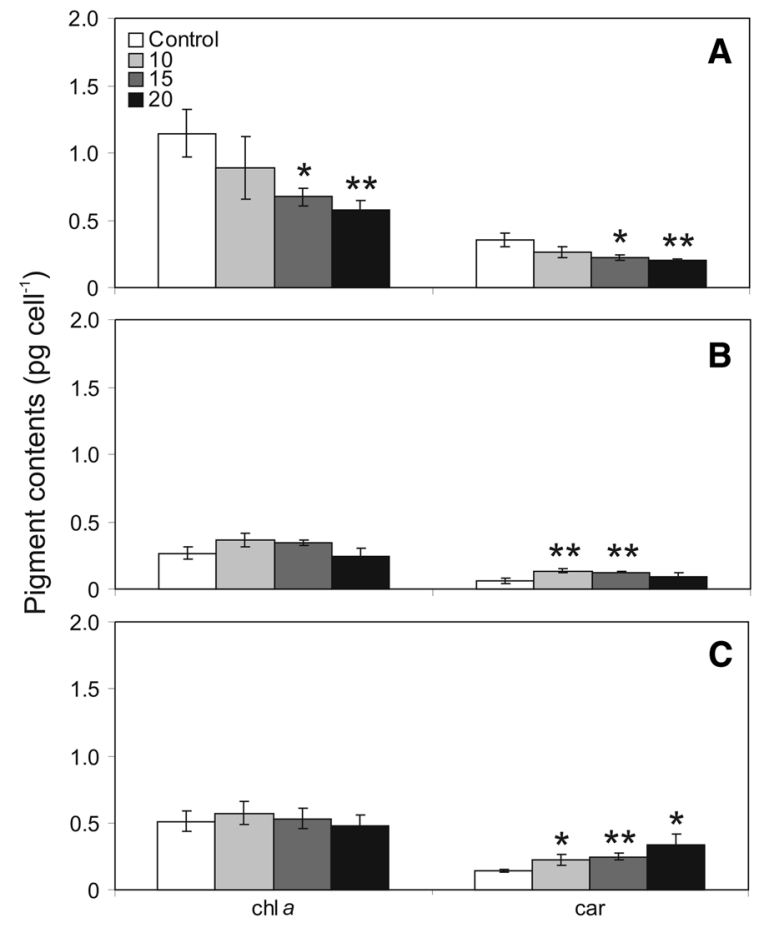

Fig. $3 \mathrm{Chl} a$ and Car contents (pg cell ${ }^{-1}$ ) of P.purpureum (A), Fistulifera sp. (B), and C. vulgaris (C) for controls and experiments with the addition of cell-free filtrate obtained from Synechocystis sp. cultures grown under varied temperatures: 10, 15 , and $20^{\circ} \mathrm{C}$ after 7 days of exposure. Values are mean \pm SD $(n=3)$. Asterisks indicate significant difference compared with control obtained with the $t$ test $(* P<0.05$; $* * P<0.01$; $* * * P<0.001)$

the control, only the treatment levels of 15 and $20^{\circ} \mathrm{C}$ showed significant differences for both Chl $a$ and Car. For Chl $a$, the reduction was, relative to control, $60 \%$ ( $t$ test, $P<0.05$ ) and $52 \%$ ( $t$ test, $P<0.01$ ), 
respectively, for each temperature level. For the Car content, the reductions were of $64 \%$ ( $t$ test, $P<0.05$ ) and $57 \%$ ( $t$ test, $P<0.01$ ), respectively. On the other hand, Fistulifera sp. and $C$. vulgaris did not show any significant effect of filtrates on the Chl $a$ content. Regarding Car content, both species showed relatively small, but statistically significant, increases. These increases were positively related with temperature, in particular for C. vulgaris.

\section{Allelopathic effect of cell-free filtrates on lipid content}

The effects of cell-free filtrate from Synechocystis sp. on lipid contents are shown in Fig. 4. The lipid content of the microalgae employed was significantly altered in all the species, but not for all the temperature levels. In $P$. purpureum, for the filtrates obtained from 10, 15, and $20^{\circ} \mathrm{C}$, the lipid content constituted, relative to the control, $151 \%$ ( $t$ test, $P<0.01$ ), $145 \%$ ( $t$ test, $P<0.01)$ and $464 \%$ ( $t$ test, $P<0.001)$, respectively (Fig. 4A). For Fistulifera sp. and $C$. vulgaris, significant differences relative to the control were found only for the filtrates from $20^{\circ} \mathrm{C}$. At the seventh day of experiment, in that treatment level, the lipid content constituted, relative to the control, 300\% ( $t$ test, $P<0.05$ ) and $130 \%$ ( $t$ test, $P<0.01$ ), respectively, for each species (Fig. 4B, C).

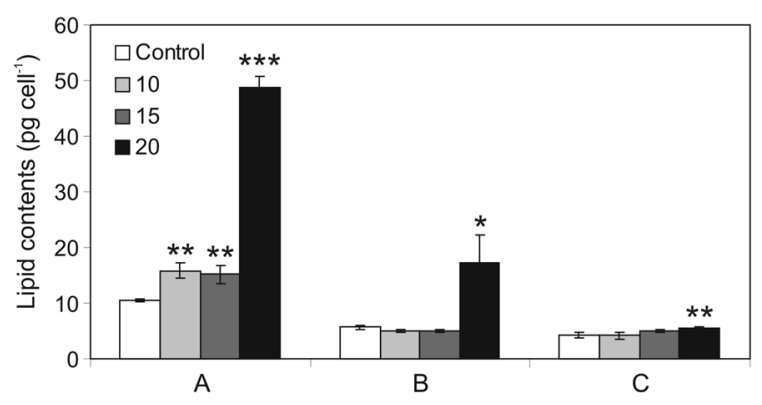

Fig. 4 Lipid contents (pg cell ${ }^{-1}$ ) of P. purpureum (A), Fistulifera sp. (B), and C. vulgaris (C) for controls and experiments with addition of cell-free filtrates obtained from Synechocystis sp. cultures grown under varied temperatures: 10, 15 , and $20^{\circ} \mathrm{C}$ after 7 days of exposure. Values are mean $\pm \mathrm{SD}$ $(n=3)$. Asterisks indicate significant difference compared with control obtained with the $t$ test $(* P<0.05 ; * * P<0.01$; $* * * P<0.001)$

\section{Discussion}

In the present study, we showed that Synechocystis sp. filtrate negatively affected several strains of microalgae. The effects were positively dependent on the temperature in which picocyanobacterium was grown, and not all the target species employed were sensitive. There are previous reports of allelopathic effects of cyanobacteria against different groups of algae: red algae (García-Espín et al., 2017), diatoms (Suikkanen et al., 2004) and green algae (Antunes et al., 2012; Żak et al., 2012; Żak \& Kosakowska, 2015). Very little information is available about allelopathic effects of picocyanobacteria (i.e., Synechococcus sp.) (Śliwińska-Wilczewska et al., 2016, 2017; ŚliwińskaWilczewska \& Latała, 2018), and none about Synechocystis sp. although one strain was already reported to show biological activity (Costa et al., 2014).

In our experiments, the most sensitive species were, depending on the parameter studied, the diatom Fistulifera sp. or the Rhodophyte Porphyridium purpureum. There is extensive information in the literature showing that species differ in their sensitivity to allelopathy (Suikkanen et al., 2004; Barreiro Felpeto \& Hairston, 2013; Barreiro Felpeto \& Vasconcelos, 2014). In general, smaller species are more sensitive, which is probably due to a higher surface to volume relationship, which may cause higher allelochemical uptake rates (Lyczkowski \& Karp-Boss, 2014). However, this is not always the case (Barreiro Felpeto \& Vasconcelos, 2014). Then, allelochemicals should have a differential impact in phytoplankton community structure.

Our experiments showed a strong negative effect of Synechocystis sp. filtrates on the maximum quantum yield of PSII of all target microalgae. There was a decrease in $F_{\mathrm{v}} / F_{\mathrm{m}}$ for $P$. purpureum and $C$. vulgaris already after the first day of exposure to cell-free filtrates. The effect in growth, however, was not evident so rapid, and significant growth decreases were observed only after three and seven days of exposure. According to this, the efficiency of PSII may be more sensitive as an indicator of the allelopathic effect than growth measured over a few days. This was also pointed out by other authors (Prince et al., 2008). This reduction of PSII efficiency may be an effect of the allelopathic mechanism for cyanobacteria (Gross, 2003). 
The changes in pigment content caused by allelochemicals seem to vary considerably across the different microalgal species. In this work, we showed significant reductions in the Chl $a$ and Car contents of $P$. purpureum. This reduction of pigment content is probably one of the main reasons for the inhibition of photosynthesis detected, as suggested by Sukenik et al. (2002) and Śliwińska-Wilczewska et al. (2017). Car contents for Fistulifera sp. and C. vulgaris increased, while their growths were inhibited. Carotenoid pigments have a protective function (e.g., Jodłowska \& Latała, 2013); therefore, increased Car contents may indicate a protective response against the stress caused by allelochemical compounds. Changes in lipid composition are known to have an important role in cell survival and reproduction under different stress effects (Lu et al., 2012). In this work, we observed that the cell-free filtrate from Synechocystis sp. affected lipid contents of $P$. purpureum, Fistulifera sp., and $C$. vulgaris, by increasing it with a positive temperaturedependent effect. Microalgae synthesize and accumulate neutral lipids in their cytoplasm which account for 20-50\% of dry biomass (Rawat et al., 2011). Lipids are synthesized and used as a reserve for situations of stress caused by nutrient depletion (Mendes \& Vermelho, 2013), salinity (Lu et al., 2012) or UV radiation (Guihéneuf et al., 2010). Detailed studies on how the lipid composition is affected by the stress caused by allelopathic compounds have been made by Poulson-Ellestad et al. (2014) and Poulin et al. (2018). Poulson-Ellestad et al. (2014) noted that allelopathic compounds produced by $K$. brevis altered cell membrane components, inhibited osmoregulation, and increased the oxidative stress of $T$. pseudonana. Poulin et al. (2018) showed that allelopathic compounds produced by dinoflagellate $K$. brevis altered the structure of the lipidomes of A. glacialis and $T$. pseudonana. These authors demonstrated that membrane-associated lipids of living T. pseudonana cells became permeable after exposing them to the compounds produced by $K$. brevis. The conclusion was that allelopathic compounds may affect lipid biosynthesis. Our findings suggest that the effect of Synechocystis allelopathy in lipid production is opposed since in general, lipid production increased. Probably, these differences have to do with the mechanism of action. While in $K$. brevis, allelochemicals disrupt membranes, in Synechocystis they seem to affect cellular metabolic processes, and thus, the increase of lipid production could be a reaction similar to what was observed under other stress conditions.

Also, it is surprising to note the increase in lipid production after clearly reduced efficiency in photosynthesis-related processes. Since lipids are costly to produce, we hypothesize that they are produced as a response to stressful conditions due to reallocating much of the energy budget, which otherwise could be used for growth (which was consequently inhibited in all the species).

The influence of abiotic factors on the production and release of allelopathic compounds is far from being understood. Our study demonstrated a positive effect of temperature on the allelopathic effect of Synechocystis sp. which was detected in growth, the maximum quantum yield of PSII, pigment, and lipid contents. Furthermore, the observed changes in our experiment may be more pronounced in co-culturing experiments, as noted by, e.g., Paul et al. (2009, 2013), Dunker et al. (2017) and Śliwińska-Wilczewska et al. (2018b). Temperature conditions influenced the production of cylindrospermopsin (CYN) and unrecognized allelopathic compounds in the cyanobacterium Cylindrospermopsis raciborskii (Woloszynska) Seenayya \& Subba Raju (Antunes et al., 2012). In this case, the allelopathic activity of filtrates from $C$. raciborskii, grown at $30^{\circ} \mathrm{C}$, exhibited the highest inhibitory activity and this effect coincided with the optimal growth of analyzed cyanobacterium. Similarly, Śliwińska-Wilczewska et al. (2016) showed that higher temperature enhanced the allelopathic activity of picocyanobacterium Synechococcus sp. What actually seems is that allelopathic compounds in these species are produced at higher rates under growth conditions close to their optimal. Future studies should examine in detail the mechanisms behind temperature effect.

Our work contributes to elucidate the effects of allelochemicals at a scale of physiological processes. However, more effort needs to be made yet to elucidate the mechanisms of actions of these compounds at a metabolic level, for which it is mandatory to identify the allelopathic compounds.

The current status of knowledge suggests that climate change will enhance the frequency and strength of harmful cyanobacterial blooms in aquatic ecosystems because higher carbon dioxide concentrations in the waters and warmer temperatures would benefit these species (Paerl \& Huisman, 2008). 
Allelopathic interactions were considered to be a potential driver of these blooms by some authors (Kubanek et al., 2005; Prince et al., 2008). Here, we have demonstrated the existence of a positive effect of temperature on the allelopathic effect of a species of picocyanobacteria. This effect, in the context of rise in sea temperature caused by climate change, could strengthen the allelopathic activity of these species in the subpolar oceanic regions. Depending on the extent to which allelopathy is important in community dynamics, as blooms of allelopathic cyanobacteria become more frequent and stronger due to climate change, stronger allelopathy should be an additional factor to be taken into account as an indirect effect of climate change.

In the present work, we conclude that picocyanobacterial allelopathy has potential to influence plankton dynamics in subpolar latitudes. The allelopathic effect was detected in different physiological parameters, and species sensitivity was not uniform. Interestingly, we detected a positive effect of temperature on allelopathic activity. Hence, this allelopathic potential could be enhanced by rising sea temperatures in the context of climate change.

Acknowledgements The authors would like to thank the Associate Editor in Chief Diego Fontaneto, and two anonymous Reviewers for their valuable comments and suggestions, which enabled the authors to improve the quality of the paper. This study was supported by BMN Grants, Poland, No. 538-G245B116-18; the FCT Project UID/Multi/04423/2013; and the Structured Program of R\&D\&I INNOVMAR - Innovation and Sustainability in the Management and Exploitation of Marine Resources (reference NORTE-01-0145-FEDER-000035 and the Research Line NOVELMAR), funded by the Northern Regional Operational Program (NORTE2020) through the European Regional Development Fund (ERDF).

Open Access This article is distributed under the terms of the Creative Commons Attribution 4.0 International License (http:// creativecommons.org/licenses/by/4.0/), which permits unrestricted use, distribution, and reproduction in any medium, provided you give appropriate credit to the original author(s) and the source, provide a link to the Creative Commons license, and indicate if changes were made.

\section{References}

Antunes, J. T., P. N. Leão \& V. M. Vasconcelos, 2012. Influence of biotic and abiotic factors on the allelopathic activity of the cyanobacterium Cylindrospermopsis raciborskii strain LEGE 99043. Microbial Ecology 64: 584-592.

Barreiro Felpeto, A. \& N. G. Hairston Jr., 2013. The influence of resource limitation on the allelopathic effect of Chlamydomonas reinhardtii on other unicellular freshwater planktonic organisms. Journal of Plankton Research 35: 1339-1344.

Barreiro Felpeto, A. \& V. M. Vasconcelos, 2014. Interactions between allelopathic properties and growth kynetics in four freshwater phytoplankton species studied by model simulations. Aquatic Ecology 48: 191-205.

Barreiro Felpeto, A., S. Śliwińska-Wilczewska, I. Złoch \& V. Vasconcelos, 2018. Light-dependent cytolysis in the allelopathic interaction between picoplanktic and filamentous cyanobacteria. Journal of Plankton Research 40: $165-177$.

Beardall, J., 2008. Blooms of Synechococcus: An Analysis of the Problem Worldwide and Possible Causative Factors in Relation to Nuisance Blooms in the Gippsland Lakes. Monash University, Clayton: 1-8.

Bligh, E. G. \& W. J. Dyer, 1959. A rapid method of total lipid extraction and purification. Canadian Journal of Biochemistry and Physiology 37: 911-917.

Brutemark, A., A. Vandelannoote, J. Engström-Öst \& S. Suikkanen, 2015. A less saline Baltic Sea promotes cyanobacterial growth, hampers intracellular microcystin production, and leads to strain-specific differences in allelopathy. PLoS ONE 10(6): e0128904.

Callieri, C., 2010. Single cells and microcolonies of freshwater picocyanobacteria: a common ecology. Journal of Limnology 69(2): 257-277.

Campbell, D., V. Hurry, A. K. Clarke, P. Gustafsson \& G. Öquist, 1998. Chlorophyll fluorescence analysis of cyanobacterial photosynthesis and acclimation. Microbiology and Molecular Biology Reviews 62: 667-683.

Cianca, R. C. C., M. S. Baptista, V. R. Lopes \& V. M. Vasconcelos, 2012. The non-protein amino acid $\beta$-N-methylamino-L-alanine in Portuguese cyanobacterial isolates. Amino Acids 42(6): 2473-2479.

Costa, M., M. Garcia, J. Costa-Rodrigues, M. S. Costa, M. J. Ribeiro, M. H. Fernandes, P. Barros, A. Barreiro Felpeto, V. Vasconcelos \& R. Martins, 2014. Exploring bioactive properties of marine cyanobacteria isolated from the Portuguese coast: high potential as a source of anticancer compounds. Marine Drugs 12: 98-114.

Costa, M. S., M. Costa, V. Ramos, P. N. Leão, A. Barreiro Felpeto, V. Vasconcelos \& R. Martins, 2015. Picocyanobacteria from a clade of marine Cyanobium revealed bioactive potential against microalgae, bacteria, and marine invertebrates. Journal of Toxicology \& Environmental Health Part A: Current Issues 78: 432-442.

Dias, F., J. T. Antunes, T. Ribeiro, J. Azevedo, V. Vasconcelos \& P. N. Leão, 2017. Cyanobacterial allelochemicals but not cyanobacterial cells markedly reduce microbial community diversity. Frontiers in Microbiology 8: 1495.

Dunker, S., J. Althammer, G. Pohnert \& C. Wilhelm, 2017. A fateful meeting of two phytoplankton species-chemical vs. cell-cell-interactions in co-cultures of the green algae Oocystis marsonii and the cyanobacterium Microcystis aeruginosa. Microbial Ecology 74: 22-32. 
Franzè, G., J. J. Pierson, D. K. Stoecker \& P. J. Lavrentyev, 2018. Diatom-produced allelochemicals trigger trophic cascades in the planktonic food web. Limnology and Oceanography 63: 1093-1108.

García-Espín, L., E. A. Cantoral, A. D. Asencio \& M. Aboal, 2017. Microcystins and cyanophyte extracts inhibit or promote the photosynthesis of fluvial algae. Ecological and management implications. Ecotoxicology 26: 658-666.

Goleski, J. A., F. Koch, M. A. Marcoval, C. C. Wall, F. J. Jochem, B. J. Peterson \& C. J. Gobler, 2010. The role of zooplankton grazing and nutrient loading in the occurrence of harmful cyanobacterial blooms in Florida Bay, USA. Estuaries and Coasts 33(5): 1202-1215.

Grama, B. S., S. Chader, D. Khelifi, B. Stenuit, C. Jeffryes \& S. N. Agathos, 2014. Characterization of fatty acid and carotenoid production in an Acutodesmus microalga isolated from the Algerian Sahara. Biomass and Bioenergy 69: 265-275.

Grasshoff, K., 1976. Methods of Seawater Analysis. Verlag Chemie Weinheim, New York.

Gross, E. M., 2003. Allelopathy of aquatic autotrophs. Critical Reviews in Plant Sciences 22(3-4): 313-339.

Guihéneuf, F., M. Fouqueray, V. Mimouni, L. Ulmann, B. Jacquette \& G. Tremblin, 2010. Effect of UV stress on the fatty acid and lipid class composition in two marine microalgae Pavlova lutheri (Pavlovophyceae) and Odontella aurita (Bacillariophyceae). Journal of Applied Phycology 22(5): 629-638.

Guillard, R. R. L., 1975. Culture of phytoplankton for feeding marine invertebrates. In Smith, W. L. \& M. H. Chanley (eds), Culture of Marine Invertebrate Animals. Plenum Press, New York.

Hall, M. O., M. J. Durako, J. W. Fourqurean \& J. C. Zieman, 1999. Decadal changes in seagrass distribution and abundance in Florida Bay. Estuaries and Coasts 22(2): 445-459.

Hattenrath-Lehmann, T. K. \& C. J. Gobler, 2011. Allelopathic inhibition of competing phytoplankton by North American strains of the toxic dinoflagellate, Alexandrium fundyense: evidence from field experiments, laboratory experiments, and bloom events. Harmful Algae 11: 106-116.

Heisler, J., P. M. Glibert, J. M. Burkholder, D. M. Anderson, W. Cochlan, W. C. Dennison, Q. Dortch, C. J. Gobler, C. Heil, E. Humphries, A. Lewitus, R. Magnien, H. Marshall, K. Sellner, D. Stockwell, D. Stoecker \& M. Suddleson, 2008. Eutrophication and harmful algal blooms: a scientific consensus. Harmful Algae 8(1): 3-13.

Houghton, J. T., Y. D. J. G. Ding, D. J. Griggs, M. Noguer, P. J. Van der Linden, X. Dai, K. Maskell \& C. A. Johnson, 2001. Climate Change 2001: The Scientific Basis. Cambridge University Press, Cambridge: 881.

IPCC, 2007. A Report of Working Group I of the Intergovernmental Panel on Climate Change. Summary for Policymakers and Technical Summary. IPCC, Geneva.

Jodłowska, S. \& A. Latała, 2013. Combined effects of light and temperature on growth, photosynthesis, and pigment content in the mat-forming cyanobacterium Geitlerinema amphibium. Photosynthetica 51(2): 202-214.

Jonsson, P. R., H. Pavia \& G. Toth, 2009. Formation of harmful algal blooms cannot be explained by allelopathic interactions. Proceedings of the National Academy of Sciences 106(27): 11177-11182.
Klin, M., F. Pniewski \& A. Latała, 2018. The characteristics of growth rate and lipids production in fourteen strains of Baltic green microalgae. Oceanological and Hydrobiological Studies 47(1): 10-18.

Kubanek, J., M. K. Hicks, J. Naar \& T. A. Villareal, 2005. Does the red tide dinoflagellate Karenia brevis use allelopathy to outcompete other phytoplankton? Limnology and Oceanography 50(3): 883-895.

Lewis Jr., W. M., 1986. Evolutionary interpretations of allelochemical interactions in phytoplankton algae. The American Naturalist 127(2): 184-194.

Lochte, K. \& C. M. Turley, 1988. Bacteria and cyanobacteria associated with phytodetritus in the deep sea. Nature 333(6168): 67.

Lu, N., D. Wei, F. Chen \& S. T. Yang, 2012. Lipidomic profiling and discovery of lipid biomarkers in snow alga Chlamydomonas nivalis under salt stress. European Journal of Lipid Science and Technology 114(3): 253-265.

Lyczkowski, E. R. \& L. Karp-Boss, 2014. Allelopathic effects of Alexandrium fundyense (Dinophyceae) on Thalassiosira cf. gravida (Bacillariophyceae): a matter of size. Journal of Phycology 50: 376-387.

Martins, R., P. Pereira, M. Welker, J. Fastner \& V. M. Vasconcelos, 2005. Toxicity of culturable cyanobacteria strains isolated from the Portuguese coast. Toxicon 46: 454-464.

Martins, R., N. Fernandez, R. Beiras \& V. M. Vasconcelos, 2007. Toxicity assessment of crude and partially purified extracts of marine Synechocystis and Synechococcus cyanobacterial strains in marine invertebrates. Toxicon 50: 791-799.

Martins, R. F., M. F. Ramos, L. Herfindal, J. A. Sousa, K. Skærven \& V. M. Vasconcelos, 2008. Antimicrobial and cytotoxic assessment of marine cyanobacteria - Synechocystis and Synechococcus. Marine Drugs 6: 1-11.

Mendes, L. B. B. \& A. B. Vermelho, 2013. Allelopathy as a potential strategy to improve microalgae cultivation. Biotechnology for Biofuels 6(1): 152.

Möller, A. \& J. K. Jansson, 1997. Quantification of genetically tagged cyanobacteria in Baltic Sea sediment by competitive PCR. BioTechniques 22: 512-518.

Moore, L. R., R. Goericke \& S. W. Chisholm, 1995. Comparative physiology of Synechococcus and Prochlorococcus: influence of light and temperature on growth, pigments, fluorescence and absorptive properties. Marine Ecology Progress Series 116: 259-275.

Oudra, B., M. Loudiki, V. Vasconcelos, B. Sabour, B. Sbiyyaa, K. Oufdou \& N. Mezrioui, 2002. Detection and quantification of microcystins from cyanobacteria strains isolated from reservoirs and ponds in Morocco. Environmental Toxicology 17: 32-39.

Paerl, H. W. \& J. Huisman, 2008. Blooms like it hot. Science 320: 57-58.

Paerl, H. W. \& J. Huisman, 2009. Climate change: a catalyst for global expansion of harmful cyanobacterial blooms. Environmental Microbiology Reports 1(1): 27-37.

Paul, V. J., 2008. Global warming and cyanobacterial harmful algal booms. In Hudnell, K. H. (ed.), Cyanobacterial Harmful Algal Blooms: State of the Science and Research Needs. Springer, New York: 239-257.

Paul, C., A. Barofsky, C. Vidoudez \& G. Pohnert, 2009. Diatom exudates influence metabolism and cell growth of co- 
cultured diatom species. Marine Ecology Progress Series 389: 61-70.

Paul, C., M. A. Mausz \& G. Pohnert, 2013. A co-culturing/ metabolomics approach to investigate chemically mediated interactions of planktonic organisms reveals influence of bacteria on diatom metabolism. Metabolomics 9: 349-359.

Poulin, R. X., S. Hogan, K. L. Poulson-Ellestad, E. Brown, F. M. Fernández \& J. Kubanek, 2018. Karenia brevis allelopathy compromises the lipidome, membrane integrity, and photosynthesis of competitors. Scientific Reports 8(1): 9572.

Poulson-Ellestad, K. L., C. M. Jones, J. Roy, M. R. Viant, F. M. Fernández, J. Kubanek \& B. L. Nunn, 2014. Metabolomics and proteomics reveal impacts of chemically mediated competition on marine plankton. Proceedings of the National Academy of Sciences of the United States of America 111: 9009-9014.

Prince, E. K., T. L. Myers \& J. Kubanek, 2008. Effects of harmful algal blooms on competitors: allelopathic mechanisms of the red tide dinoflagellate Karenia brevis. Limnology and Oceanography 53: 531-541.

R Core Team, 2017. R: A Language and Environment for Statistical Computing. R Foundation for Statistical Computing, Vienna, Austria.

Rawat, I., R. R. Kumar, T. Mutanda \& F. Bux, 2011. Dual role of microalgae: phycoremediation of domestic wastewater and biomass production for sustainable biofuels production. Applied Energy 88(10): 3411-3424.

Schmidt, W., G. Drews, J. Weckesser \& H. Mayer, 1980. Lipopolysaccharides in four strains of the unicellular cyanobacterium Synechocystis. Archives of Microbiology 127: 217-222.

Śliwińska-Wilczewska, S. \& A. Latała, 2018. Allelopathic activity of the bloom-forming picocyanobacterium Synechococcus sp. on the coexisting microalgae: the role of eutrophication. International Review of Hydrobiology 103: 37-47.

Śliwińska-Wilczewska, S., F. Pniewski \& A. Latała, 2016. Allelopathic activity of the picocyanobacterium Synechococcus sp. under varied light, temperature and salinity conditions. International Review of Hydrobiology 101: $62-79$.

Śliwińska-Wilczewska, S., J. Maculewicz, A. Barreiro Felpeto, V. Vasconcelos \& A. Latała, 2017. Allelopathic activity of the picocyanobacterium Synechococcus sp. on filamentous cyanobacteria. Journal of Experimental Marine Biology and Ecology 496: 16-21.
Śliwińska-Wilczewska, S., J. Maculewicz, A. Barreiro Felpeto \& A. Latała, 2018a. Allelopathic and bloom-forming picocyanobacteria in a changing world. Toxins 10: 48.

Śliwińska-Wilczewska, S., A. Barreiro Felpeto, J. Maculewicz, A. Sobczyk, V. Vasconcelos \& A. Latała, 2018b. Allelopathic activity of the picocyanobacterium Synechococcus sp. on unicellular eukaryote planktonic microalgae. Marine and Freshwater Research 69: 1472-1479.

Sorokin, Y. I. \& F. Dallocchio, 2008. Dynamics of phosphorus in the Venice lagoon during a picocyanobacteria bloom. Journal of Plankton Research 30(9): 1019-1026.

Sorokin, Y. I. \& O. Y. Zakuskina, 2010. Features of the Comacchio ecosystem transformed during persistent bloom of picocyanobacteria. Journal of Oceanography 66: 373-387.

Strickland, I. D. H. \& T. R. Parsons, 1972. A practical handbook of seawater analysis. Journal of the Fisheries Research Board of Canada 167: 1-310.

Suikkanen, S., G. O. Fistarol \& E. Granéli, 2004. Allelopathic effects of the Baltic cyanobacteria Nodularia spumigena, Aphanizomenon flos-aquae and Anabaena lemmermannii on algal monocultures. Journal of Experimental Marine Biology and Ecology 308: 85-101.

Sukenik, A., R. Eshkol, A. Livne, O. Hadas, M. Rom, D. Tchernov, A. Vardi \& A. Kaplan, 2002. Inhibition of growth and photosynthesis of the dinoflagellate Peridinium gatunense by Microcystis sp. (cyanobacteria): a novel allelopathic mechanism. Limnology and Oceanography 47(6): 1656-1663.

Vareli, K., E. Zarali, G. S. Zacharioudakis, G. Vagenas, V. Varelis, G. Pilidis, E. Briasoulis \& I. Sainis, 2012. Microcystin producing cyanobacterial communities in Amvrakikos Gulf (Mediterranean Sea, NW Greece) and toxin accumulation in mussels (Mytilus galloprovincialis). Harmful Algae 15: 109-118.

Worden, A. Z. \& S. Wilken, 2016. A plankton bloom shifts as the ocean warms. Science 354: 287-288.

Żak, A. \& A. Kosakowska, 2015. The influence of extracellular compounds produced by selected Baltic cyanobacteria, diatoms and dinoflagellates on growth of green algae Chlorella vulgaris. Estuarine, Coastal and Shelf Science 167: 113-118.

Żak, A., M. Musiewicz \& A. Kosakowska, 2012. Allelopathic activity of the Baltic cyanobacteria against microalgae. Estuarine, Coastal and Shelf Science 112: 4-10.

Publisher's Note Springer Nature remains neutral with regard to jurisdictional claims in published maps and institutional affiliations. 